\title{
Gambaran Persepsi dan Pengetahuan Kebersihan Tangan pada Pengunjung Intensive Care Unit Rumah Sakit Akademik Universitas Gadjah Mada Yogyakarta
}

\section{Hand Hygiene Among Hospital Visitor: A survey of Perception and Knowledge in Intensive Care Unit at Gadjah Mada University Academic Hospital Yogyakarta}

\author{
Sulistina Alifah Purbaningrum ${ }^{1}$, Sri Setiyarini ${ }^{2}$, Happy Indah Kusumawati ${ }^{2 *}$, Eri Yanuar \\ Akhmad Budi Sunaryo ${ }^{3}$ \\ ${ }^{1}$ Program Studi Ilmu Keperawatan, Fakultas Kedokteran, Kesehatan Masyarakat, dan \\ Keperawatan, Universitas Gadjah Mada, Yogyakarta \\ 2Departemen Keperawatan Dasar dan Emergensi, Program Studi IImu Keperawatan, \\ Fakultas Kedokteran, Kesehatan Masyarakat, dan Keperawatan, Universitas Gadjah Mada, \\ Yogyakarta \\ ${ }^{3}$ Rumah Sakit Akademik Universitas Gadjah Mada, Yogyakarta
}

\begin{abstract}
Background: Intensive Care Unit (ICU) patients are immunosuppressive and susceptible to infection. Their visit toward ICU may increase pathogen contamination and infection transmission probability. One of the procedures to prevent infection transmission is hand hygiene. On the other hand, perception and knowledge among ICU visitors related to hand hygiene is still under-researched.

Objective: Describing the hand hygiene perception and knowledge of ICU visitors at Gadjah Mada University (UGM) Academic Hospital Yogyakarta.

Methods: This research was a descriptive study using survey. Participants were 100 visitors at the UGM Academic Hospital who visited ICU on December 2019. Data were collected by using a questionnaire of visitors' perception and knowledge of hand hygiene that refers to World Health Organisation 2009 guidance. Univariate analysis was utilized to analyze the data.

Results: Most of ICU visitors had good perception (61\%) and good knowledge (53\%). The best domain category for visitors' perception was toward the availability of hand hygiene facilities and for visitors' knowledge domain was toward hand hygiene media.

Conclusion: Most of the ICU visitors at UGM Academic Hospital has a good perception and knowledge related to hand hygiene.
\end{abstract}

Keywords: hand hygiene, knowledge, perception, visitor

\begin{abstract}
ABSTRAK
Latar belakang: Pasien di Intensive Care Unit (ICU) memiliki kondisi yang imunosupresif sehingga rentan terhadap infeksi. Kunjungan ke ICU meningkatkan kontaminasi patogen dan berpotensi menularkan infeksi. Salah satu langkah untuk mencegah terjadinya penularan infeksi adalah hand hygiene. Aspek yang dapat memengaruhi hand hygiene adalah persepsi dan pengetahuan tentang hand hygiene. Di sisi lain, penelitian terkait hand hygiene oleh pengunjung di ICU masih jarang dilakukan.

Tujuan: Mengetahui gambaran persepsi dan pengetahuan hand hygiene pengunjung ICU RSA UGM Yogyakarta.

Metode: Penelitian ini adalah jenis penelitian deskriptif dengan rancangan penelitian survei. Responden dalam penelitian ini adalah pengunjung ICU RSA UGM Yogyakarta yang berjumlah 100 orang. Metode pengambilan data menggunakan kuesioner pengetahuan dan persepsi hand hygiene pengunjung yang mengacu pada panduan WHO tahun 2009. Pengambilan data dilakukan selama bulan Desember 2019. Analisis yang digunakan pada penelitian ini adalah analisis univariat.

Hasil: Mayoritas pengunjung memiliki persepsi yang baik (61\%) dan pengetahuan yang baik $(53 \%)$. Pengunjung memiliki persepsi yang baik pada domain ketersediaan fasilitas hand hygiene. Mayoritas pengunjung memiliki pengetahuan yang baik pada domain media hand hygiene.
\end{abstract}


Kesimpulan: Sebagian besar pengunjung ICU RSA UGM Yogyakarta mempunyai persepsi dan pengetahuan hand hygiene dengan kategori baik.

Kata kunci: kebersihan tangan, pengetahuan, pengunjung, persepsi

\section{PENDAHULUAN}

Intensive Care Unit (ICU) merupakan salah satu unit di rumah sakit untuk merawat pasien dengan gangguan fungsi yang membutuhkan pengobatan intensif, teknologi tinggi, serta tindak lanjut lebih ketat. ${ }^{1}$ Pasien ICU menjalani prosedur invasif dan memiliki kondisi yang imunosupresif sehingga rentan terhadap infeksi. ${ }^{2}$ Pasien yang dirawat di ICU memiliki risiko lima hingga delapan kali lebih tinggi terkena infeksi. ${ }^{3}$

Penularan infeksi, selain ditransmisikan oleh pasien dan tenaga kesehatan, juga dapat ditransmisikan oleh pengunjung. ${ }^{4}$ Diketahui, kunjungan ke ICU dapat meningkatkan kontaminasi patogen dan lingkungan. ${ }^{5}$

Selain berdampak kepada pasien, pengunjung juga dapat memperoleh infeksi dari rumah sakit. ${ }^{3} \mathrm{Hal}$ tersebut dapat diminimalisir jika pengunjung melakukan hand hygiene dengan benar di pintu masuk ICU. ${ }^{4}$ Hand hygiene adalah cara yang efektif untuk mencegah penularan infeksi. Hand hygiene selain harus dipahami oleh tenaga kesehatan juga perlu dipahami oleh pengunjung rumah sakit untuk mengurangi risiko kontaminasi mikroba. ${ }^{5}$

Di Indonesia, persentase pengetahuan pengunjung tentang kebersihan tangan berada dalam kategori rendah $(47,7 \%)$ dan perilaku kebersihan tangan pun masih buruk, yakni sebesar $46,7 \% .{ }^{6}$ Pada penelitian lain, perilaku hand hygiene pengunjung baik sebelum kontak dengan pasien, setelah kontak dengan pasien, dan setelah kontak dengan lingkungan pasien yang tidak sesuai rekomendasi Centers for Disease Control (CDC) adalah sebesar 89\%. ${ }^{7}$ Perilaku tersebut dapat dilatarbelakangi oleh pengetahuan dan persepsi.

Studi yang meneliti tentang pengetahuan dan persepsi hand hygiene pengunjung rumah sakit maupun ruang ICU belum banyak dilakukan. Tujuan penelitian ini adalah untuk mengetahui gambaran persepsi dan pengetahuan hand hygiene pada pengunjung ICU Rumah Sakit Akademik Universitas Gadjah Mada (RSA UGM).

\section{METODE PENELITIAN}

Penelitian ini merupakan jenis penelitian deskriptif dengan desain survei. Penelitian dilakukan di ruang ICU RSA UGM Yogyakarta. Sampel penelitian ini adalah pengunjung ICU dengan kriteria inklusi, pengunjung pasien yang memasuki ruang ICU, mampu berbahasa Indonesia dengan baik, bersedia menjadi responden, berusia $\geq 18$ tahun, dan mampu mengisi kuesioner secara mandiri. Kriteria eksklusi meliputi pengunjung yang sudah pernah menjadi responden. Teknik pengambilan sampel yang digunakan yaitu consecutive sampling. Besar sampel yang digunakan yaitu 100 responden. 
Instrumen dalam penelitian ini adalah kuesioner persepsi dan kuesioner pengetahuan pengunjung, yang dikembangkan oleh peneliti dan mengacu pada $\mathrm{WHO}^{10}$ pada tahun 2009 serta jurnal pendukung lainnya. Instrumen telah melalui uji validitas isi, uji keterbacaan, dan uji reliabilitas yang dilakukan pada 30 pengunjung $R S$. Uji validitas isi menggunakan penghitungan Content Validity Index (CVI). Instrumen persepsi dan pengetahuan mendapat skor Scale Content Validity Index (S-CVI 1,00). Uji keterbacaan dilakukan untuk mengetahui jika ada kata-kata yang sulit dipahami calon responden penelitian serta untuk mengecek perkiraan durasi waktu pengisian. Instrumen diperbaiki sesuai saran dari responden dalam uji keterbacaan. Uji reliabilitas dilakukan menggunakan nilai Alpha Cronbach. Instrumen persepsi dan pengetahuan mendapat nilai reliabilitas masing-masing 0,61 . Peneliti melakukan eliminasi pada item pertanyaan nomor 1, 8, 9, dan 13 pada instrumen persepsi.

Analisis pada persepsi dan pengetahuan berdasarkan skor jawaban responden. Data skor persepsi dan pengetahuan responden dianalisis dari sebaran data. Hasil analisis menunjukkan bahwa data tidak terdistribusi normal, maka pengkategorian data menggunakan nilai median. Data dikategorikan menjadi baik dan buruk. Persepsi atau pengetahuan baik apabila skor responden lebih dari atau sama dengan median.

Penelitian ini telah mendapat persetujuan kelayakan etik dari Komisi Etik FK-KMK UGM Yogyakarta dengan nomor KE/FK/1213/EC/2019. Peneliti juga menggunakan informed consent sebagai persetujuan untuk menjadi responden penelitian.

\section{HASIL}

Responden pada penelitian ini adalah pengunjung pasien di ruang ICU RSA UGM Yogyakarta. Total responden dalam penelitian ini sebanyak 100 orang. Karakteristik responden dijabarkan dalam Tabel 1.

Pada Tabel 1, rentang usia responden adalah 18-65 tahun yang didominasi responden usia dewasa (52\%). Sebagian besar responden menempuh pendidikan menengah (62\%), dengan pekerjaan karyawan swasta (38\%) dan ibu rumah tangga (26\%). Mayoritas responden memiliki hubungan keluarga dengan pasien sebagai keluarga inti yaitu ibu, ayah, isteri, anak, dan saudara kandung (43\%) dan kerabat (32\%).

Mayoritas responden (83\%) memiliki pengalaman memperoleh informasi tentang hand hygiene. Sebanyak 32\% memilih tenaga kesehatan sebagai sumber informasi mengenai hand hygiene. Selain itu, mayoritas responden (84\%) juga memiliki pengalaman pernah berkunjung ke rumah sakit.

Tingkat persepsi hand hygiene pada responden ditampilkan pada Tabel 2. Berdasarkan Tabel 2, sebagian besar responden (61\%) memiliki persepsi yang baik terhadap hand hygiene. Pengkategorian tingkat pengetahuan menggunakan nilai median karena data tidak 
terdistribusi normal. Responden dikategorikan memiliki persepsi baik, apabila skor persepsi lebih dari atau sama dengan 31 (skor persepsi $\geq 31$ ).

Tabel 1. Distribusi frekuensi karakteristik pengunjung ruang ICU RSA UGM Yogyakarta pada bulan Desember $2019(n=100)$

\begin{tabular}{|c|c|c|}
\hline Karakteristik & Frekuensi (f) & Persentase (\%) \\
\hline \multicolumn{3}{|l|}{ Usia } \\
\hline Remaja (18-25 tahun) & 26 & 26,0 \\
\hline Dewasa (26-45 tahun) & 52 & 52,0 \\
\hline Lansia (46-65 tahun) & 22 & 22,0 \\
\hline \multicolumn{3}{|l|}{ Jenis kelamin } \\
\hline Laki-laki & 32 & 32,0 \\
\hline Perempuan & 68 & 68,0 \\
\hline \multicolumn{3}{|l|}{ Pendidikan terakhir } \\
\hline Dasar & 1 & 1,0 \\
\hline Menengah & 62 & 62,0 \\
\hline Tinggi & 34 & 34,0 \\
\hline Tidak sekolah & 3 & 3,0 \\
\hline \multicolumn{3}{|l|}{ Pekerjaan } \\
\hline Ibu rumah tangga & 25 & 25,0 \\
\hline PNS & 14 & 14,0 \\
\hline TNI/Polri/wiraswasta & 12 & 12,0 \\
\hline Karyawan & 38 & 38,0 \\
\hline Mahasiswa/pelajar & 11 & 11,0 \\
\hline \multicolumn{3}{|l|}{ Hubungan dengan pasien } \\
\hline Keluarga inti & 43 & 43,0 \\
\hline Kerabat & 32 & 32,0 \\
\hline Rekan/teman & 22 & 22,0 \\
\hline \multicolumn{3}{|c|}{ Pernah memperoleh informasi hand hygiene } \\
\hline Ya & 83 & 83,0 \\
\hline Tidak & 17 & 17,0 \\
\hline \multicolumn{3}{|l|}{ Sumber Informasi hand hygiene ${ }^{*}$} \\
\hline Tenaga kesehatan & 47 & 32,2 \\
\hline Media di RS & 35 & 24,0 \\
\hline Media di luar RS & 29 & 19,9 \\
\hline Keluarga & 9 & $6,2,0$ \\
\hline Teman & 5 & 3,4 \\
\hline Lainnya & 4 & 2,7 \\
\hline \multicolumn{3}{|l|}{ Pernah Berkunjung ke RS } \\
\hline $\mathrm{Ya}$ & 84 & 84,0 \\
\hline Tidak & 16 & 16,0 \\
\hline
\end{tabular}

Tabel 2. Tingkat persepsi hand hygiene pengunjung ICU RSA UGM Yogyakarta pada bulan Desember $2019(n=100)$

\begin{tabular}{llcccc}
\hline Tingkat Persepsi & $\mathbf{f ( \% )}$ & Median & Mean $(\overline{\boldsymbol{x}})$ & $\mathbf{\pm S D}$ & Min-Max \\
\hline Persepsi baik & $61(61)$ & 31,00 & 31,44 & 2,413 & $26-38$ \\
Persepsi buruk & $39(39)$ & & & & \\
\hline
\end{tabular}




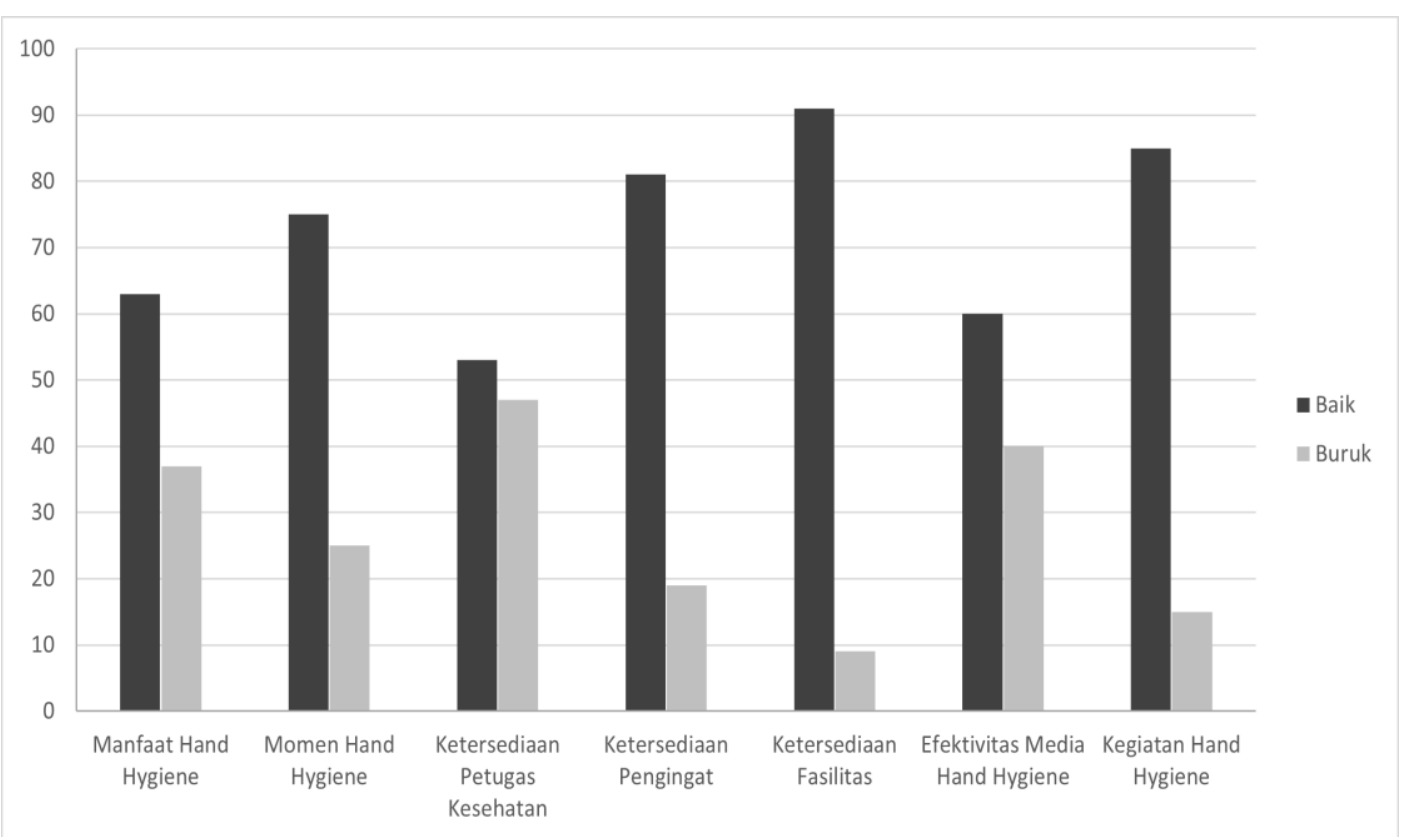

Gambar 1. Distribusi persepsi hand hygiene pengunjung ICU RSA UGM Yogyakarta pada Bulan Desember $2019(n=100)$

Gambar 1 menunjukkan bahwa mayoritas responden memiliki persepsi yang baik tentang ketersediaan fasilitas. Di sisi lain, pada domain ketersediaan petugas kesehatan, responden dengan persepsi baik dan persepsi buruk jumlahnya hampir sama.

Tabel 3. Tingkat pengetahuan hand hygiene pengunjung ICU RSA UGM Yogyakarta pada bulan Desember $2019(n=100)$

\begin{tabular}{lccccc}
\multicolumn{7}{c}{ pada bulan Desember 2019 $(\mathrm{n}=100)$} \\
\hline Tingkat Pengetahuan & $\mathbf{f}(\%)$ & Median & Mean $(\overline{\mathbf{x}})$ & $\mathbf{\pm S D}$ & Min-Max \\
\hline Pengetahuan baik & $53(53)$ & 7,00 & 6,58 & 1,759 & $2-10$ \\
Pengetahuan buruk & $47(47)$ & & & & \\
\hline
\end{tabular}

Berdasarkan Tabel 3, responden dengan pengetahuan yang baik sebanyak $53 \%$. Pengkategorian tingkat pengetahuan ini menggunakan nilai median karena data tidak terdistribusi normal. Responden dinilai memiliki pengetahuan yang baik apabila skor pengetahuan lebih dari atau sama dengan 7 (skor pengetahuan $\geq 7$ ).

Gambar 2 menunjukkan bahwa mayoritas responden memiliki pengetahuan yang baik tentang media hand hygiene. Di sisi lain, sebagian responden memiliki pengetahuan yang buruk tentang momen hand hygiene. 


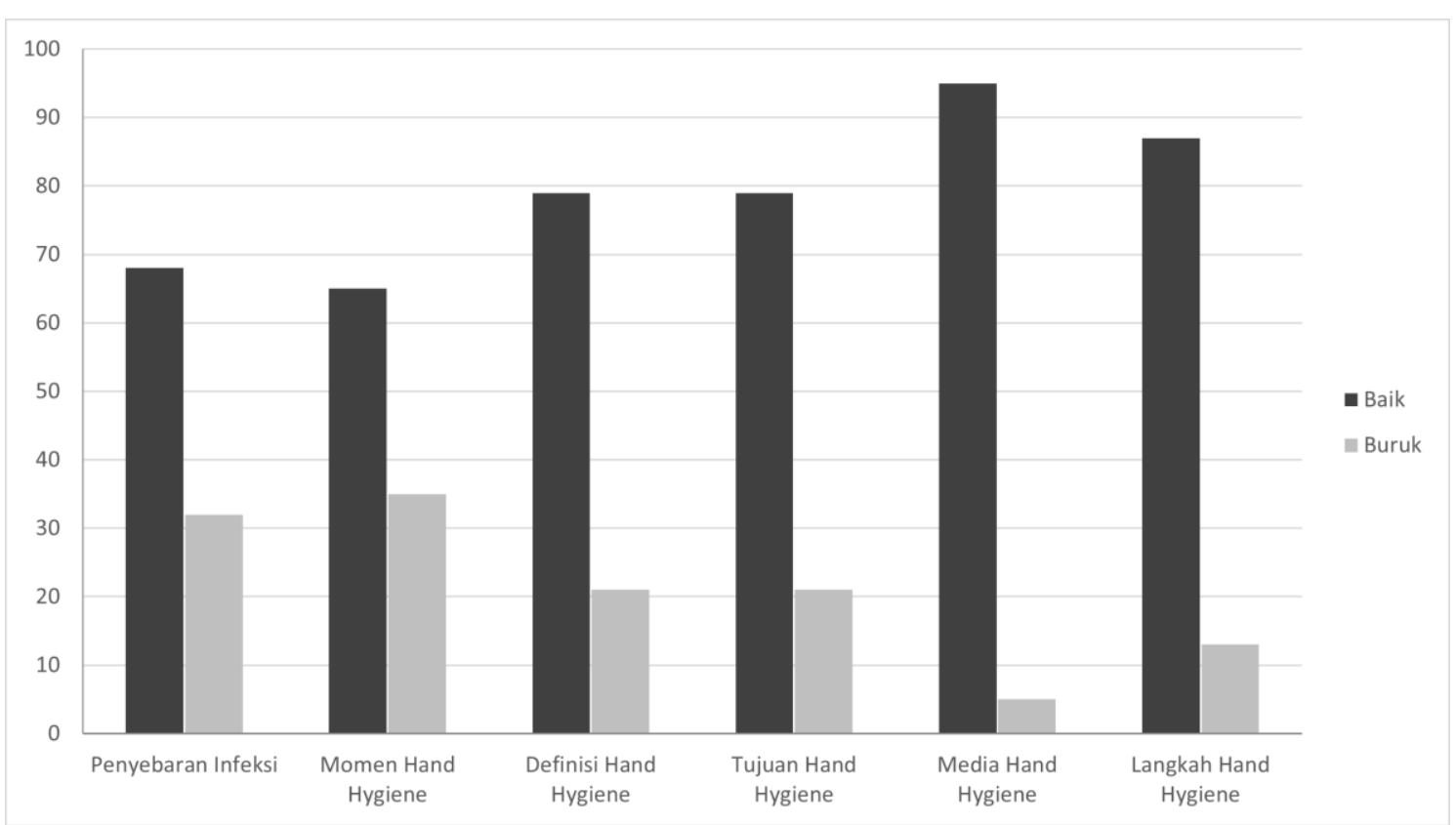

Gambar 2. Distribusi pengetahuan hand hygiene pengunjung ICU RSA UGM Yogyakarta pada bulan Desember $2019(n=100)$

\section{PEMBAHASAN}

Responden dalam penelitian ini adalah pengunjung ICU RSA UGM Yogyakarta sebanyak 100 orang. Mayoritas responden berada pada usia dewasa (52\%). Usia dewasa memiliki tanggung jawab dalam keluarga, peran sebagai orangtua, dan terlibat dalam hubungan sosial masyarakat, dalam hal ini adalah menunggu atau menjenguk pasien di rumah sakit. ${ }^{11}$

Sebagian besar responden berjenis kelamin perempuan. Sistem sosial yang mengakibatkan terjadinya perbedaan hak dan kewajiban tersebut. Hal ini menimbulkan perbedaan partisipasi karena perempuan biasanya lebih rajin berpartisipasi dalam kegiatan masyarakat, misalnya rajin mengikuti penyuluhan, menjenguk pasien di rumah sakit, dan sebagainya. ${ }^{12}$

Pendidikan responden sebagian besar adalah tingkat pendidikan menengah, atau lebih spesifik yaitu SMA. Sasaran pendidikan di Indonesia menunjukkan bahwa penduduk Indonesia lebih banyak menempuh pendidikan sampai tingkat menengah. ${ }^{13}$

Sebagian besar responden berstatus sebagai ibu rumah tangga dan bekerja sebagai karyawan. Hal ini didukung dengan usia responden yang mayoritas dewasa atau usia produktif. Selain itu, peran wanita/ibu lebih tinggi dalam hal merawat keluarga yang sakit.

Pada penelitian ini, responden merupakan keluarga inti, kerabat, dan rekan pasien. Sebagian besar responden adalah keluarga inti pasien yang meliputi orangtua, suami/isteri, anak, maupun saudara kandung. Kondisi pasien di ICU RSA UGM Yogyakarta yang kritis kerap membutuhkan kehadiran keluarga untuk memberi rasa nyaman serta untuk komunikasi terkait perawatan. ${ }^{14,15}$ 
Mayoritas responden pernah memperoleh informasi terkait hand hygiene. Sebagian besar memperoleh informasi dari tenaga kesehatan dan media di rumah sakit. Edukasi yang jelas secara lisan oleh tenaga kesehatan serta media lain seperti poster dan stiker diperlukan untuk pengunjung rumah sakit karena dapat meningkatkan kepatuhan hand hygiene. ${ }^{16}$

Mayoritas responden juga memiliki pengalaman berkunjung ke rumah sakit. Pengalaman berkunjung ke rumah sakit ini dapat meningkatkan paparan informasi tentang hand hygiene sehingga akan membentuk kepatuhan hand hygiene. ${ }^{17}$ Proses pengalaman berulang akan membentuk individu berperilaku seperti yang diharapkan. ${ }^{9}$

Sebanyak $61 \%$ responden memiliki persepsi hand hygiene yang baik. Persepsi yang baik ini dapat didukung oleh usia responden yang sebagian besar berusia remaja dan dewasa. Usia berkaitan dengan proses penafsiran terhadap stimulus. ${ }^{18}$ Kapasitas indra pada usia muda bekerja lebih baik untuk mempersepsikan suatu objek. ${ }^{19}$ Pada penelitian Hobbs et al. ${ }^{3}$ menunjukkan bahwa responden berusia muda memiliki persepsi yang baik terhadap penggunaan antiseptik alkohol di rumah sakit.

Jenis kelamin responden dalam penelitian ini sebagian besar adalah perempuan, juga dapat mendukung persepsi yang baik terhadap hand hygiene. Hal ini disebabkan karena wanita lebih sadar terhadap risiko terkena infeksi, ${ }^{20}$ sehingga mendukung adanya minat terhadap hand hygiene yang merupakan salah satu faktor pembangun persepsi. ${ }^{21}$

Persepsi yang baik juga dapat dipengaruhi oleh pengalaman mendapat informasi dan pengalaman menjenguk atau merawat pasien di rumah sakit. Pengunjung dengan pengalaman merawat pasien di rumah sakit dan mendapat edukasi atau pelatihan hand hygiene, akan memiliki persepsi yang lebih baik pula. ${ }^{22}$

Penelitian ini menunjukkan bahwa responden memiliki persepsi yang baik terhadap domain manfaat hand hygiene. Responden menganggap hand hygiene efektif untuk mencegah penularan infeksi. Hal ini sejalan dengan penelitian sebelumnya oleh Foà et al. ${ }^{20}$ dalam Model Promosi Kesehatan oleh Pender ${ }^{21}$ yang merupakan persepsi manfaat, yaitu ketika responden memandang secara positif bahwa suatu tindakan memiliki manfaat terhadap kesehatan dirinya.

Responden pada penelitian ini memiliki persepsi yang baik pada domain momen hand hygiene. Pada domain ini, seluruh responden menganggap hand hygiene perlu dilakukan sebelum dan setelah menjenguk pasien. Persepsi ini dapat dibangun oleh faktor kekuatan stimulus, seperti ketika perawat sering mengingatkan responden untuk melakukan hand hygiene. ${ }^{19}$

Pada domain efektivitas bahan hand hygiene, responden yang memiliki persepsi bahwa melakukan hand hygiene menggunakan sabun dan air mengalir lebih efektif, lebih banyak daripada responden dengan persepsi melakukan hand hygiene menggunakan alkohol. Penggunaan pembersih tangan berbasis alkohol di tatanan rumah sakit lebih disarankan 
karena lebih efektif membunuh kuman penyebab infeksi nosokomial, meningkatkan frekuensi membersihkan tangan, serta mengurangi terjadinya infeksi nosokomial. ${ }^{22}$ Dalam penelitian sebelumnya, responden mencuci tangan menggunakan sabun ketika di rumah, namun responden akan menggunakan antiseptik alkohol ketika berada di rumah sakit. ${ }^{20}$ Persepsi responden dalam penelitian ini dapat dipengaruhi karena intensitas yang lebih sedikit terhadap penggunaan antiseptik alkohol. ${ }^{19}$

Pada domain ketersediaan petugas kesehatan, mayoritas responden memiliki persepsi yang baik. Mayoritas responden juga merasa perlu mendapatkan informasi dan diajarkan langsung cara melakukan hand hygiene yang benar oleh petugas kesehatan. Memberikan informasi tentang hand hygiene kepada pengunjung rumah sakit bertujuan untuk meningkatkan kesadaran dan membangun persepsi yang baik terhadap hand hygiene. ${ }^{22}$ Pemberian edukasi terkait hand hygiene harus selalu berjalan karena pengunjung rumah sakit adalah populasi yang dinamis. ${ }^{6}$

Ketersediaan petugas kesehatan sebaiknya juga didukung dengan ketersediaan fasilitas hand hygiene dan pengingat. Pada domain ketersediaan fasilitas, mayoritas responden memiliki persepsi yang baik. Responden merasa mudah untuk menemukan fasilitas hand hygiene yaitu antiseptik alkohol. Hal ini perlu menjadi perhatian karena lokasi penempatan fasilitas hand hygiene berpengaruh terhadap kepatuhan melakukan hand hygiene. ${ }^{22}$ Program Pengendalian dan Pencegahan Infeksi di rumah sakit, juga memerlukan dukungan infrastruktur yang memadai. ${ }^{24}$

Pada domain ketersediaan pengingat, sebagian besar responden memiliki persepsi yang baik. Responden merasa perlu diingatkan melalui poster maupun oleh petugas kesehatan. Poster pengingat yang dipasang dengan pesan yang tepat, berwarna mencolok, serta jelas terbaca, dinilai dapat mendukung kepatuhan hand hygiene pengunjung. ${ }^{24,25}$

Sebagian besar responden memiliki persepsi yang baik terhadap kegiatan hand hygiene. Responden merasa dirinya melakukan hand hygiene atas kesadaran diri dan merasa mampu melakukan hand hygiene dengan benar. Memiliki persepsi kemampuan diri yang baik ini merupakan faktor penentu seseorang melakukan perilaku kesehatan tertentu ${ }^{9}$. Hal ini sejalan dengan penelitian sebelumnya. ${ }^{8,20}$

Secara umum, sebagian besar responden memiliki pengetahuan hand hygiene yang baik (53\%). Pengetahuan yang baik ini, salah satunya didukung oleh mayoritas responden yang pernah memperoleh informasi terkait hand hygiene. Pengalaman responden menerima edukasi terkait hand hygiene ini dapat meningkatkan pengetahuan karena berkaitan dengan pengalaman pengindraan terhadap suatu objek, sehingga menghasilkan pemahaman. ${ }^{18,26}$

Pengetahuan yang baik ini dapat pula didukung oleh tingkat pendidikan. Pendidikan mendukung mudahnya penerimaan informasi. ${ }^{18}$ Edukasi yang diberikan selama menempuh 
pendidikan di sekolah dapat berperan terhadap pemahaman responden tentang hand hygiene. ${ }^{3,20}$

Faktor pekerjaan juga dapat memengaruhi pengetahuan. Pada penelitian ini, terdapat responden yang bekerja sebagai staf rumah sakit dan memiliki skor pengetahuan hand hygiene tertinggi. Jenis pekerjaan mendukung kemudahan responden tersebut untuk terpapar atau mengakses informasi. ${ }^{18}$ Pengetahuan yang baik pada tenaga kesehatan disebabkan karena pihak manajemen rumah sakit rutin menyelenggarakan pelatihan terkait hand hygiene, begitu pula pada lingkungan kerja lain, seperti adanya role model untuk melakukan hand hygiene. ${ }^{27}$

Penelitian ini menunjukkan hasil bahwa responden memiliki pengetahuan yang baik tentang penyebaran infeksi. Responden memiliki pengetahuan yang baik mengenai perantara penyebaran kuman pada pasien di rumah sakit. Responden juga memiliki pengetahuan bahwa mereka dapat menularkan penyakit jika tidak melakukan hand hygiene. Hal ini disebabkan karena responden sering diingatkan oleh perawat yang bertugas di ruang ICU ketika hendak menjenguk pasien. Selain itu, juga didukung oleh kesadaran diri responden tentang penularan infeksi. Diketahui bahwa transmisi patogen penyebab infeksi dapat diperoleh dari pasien, tenaga kesehatan, maupun pengunjung. ${ }^{3}$ Oleh karena itu, pengunjung pun memiliki keterlibatan dalam kejadian infeksi. ${ }^{6}$ Selain itu, pengunjung juga melakukan kontak dengan pasien dan lingkungan sekeliling pasien. Hal tersebut berpotensi menularkan infeksi kepada pengunjung. ${ }^{28}$

Pada domain definisi hand hygiene didapatkan hasil bahwa mayoritas responden memiliki pengetahuan yang baik. Sebagian besar responden dalam penelitian ini mengetahui media dan durasi untuk melakukan hand hygiene sesuai Panduan Hand Hygiene WHO. ${ }^{10}$ Selain itu, petunjuk yang terpasang di ruang tunggu pasien pun berlandaskan panduan WHO tersebut.

Responden memiliki pengetahuan yang baik tentang tujuan hand hygiene. Sejalan dengan penelitian Foa et al. ${ }^{20}$ bahwa pengunjung mengetahui tujuan hand hygiene untuk mencegah penyebaran penyakit. Hal ini karena pengunjung telah mendapatkan cukup edukasi.

Pada domain media hand hygiene, sebagian besar responden mengetahui media yang digunakan untuk melakukan hand hygiene. Namun, hanya sebagian kecil responden yang mengetahui efektivitas antiseptik berbasis alkohol. Hal ini sejalan dengan penelitian sebelumnya. ${ }^{29}$ Antiseptik berbasis alkohol adalah standar bagi fasilitas kesehatan dan telah digunakan secara umum di rumah sakit, selain itu juga efektif dalam membersihkan tangan dari mikroorganisme patogen. ${ }^{10}$ Melakukan hand hygiene menggunakan alkohol terbukti menurunkan angka kejadian infeksi di ICU. ${ }^{30}$

Pada domain langkah melakukan hand hygiene, responden juga memiliki pengetahuan yang baik. Pada penelitian ini, responden mengetahui durasi melakukan hand hygiene, namun belum mengetahui urutan langkah hand hygiene yang tepat. Pengetahuan tentang langkah 
hand hygiene dapat ditingkatkan dengan pemberian edukasi melalui demonstrasi. ${ }^{31}$ Sebenarnya, responden telah mendapat edukasi dari perawat ruang ICU, tetapi responden jarang mengaplikasikan hand hygiene sesuai langkah yang tepat.

Pada penelitian ini terlihat bahwa belum banyak responden yang memiliki pengetahuan yang baik pada domain momen hand hygiene. Pandangan responden terhadap rumah sakit sebagai tempat yang "bersih" dapat mengurangi motivasi responden untuk melakukan hand hygiene. ${ }^{32}$ Pemberian edukasi tentang momen hand hygiene ini penting dilakukan kepada responden agar dapat melakukan hand hygiene dengan tepat. ${ }^{33}$ Peran tenaga kesehatan diperlukan untuk menjelaskan lebih detail tentang momen hand hygiene di fasilitas kesehatan, sehingga keluarga atau pengunjung pasien dapat meningkatkan pengetahuan, serta dapat mengajarkan kembali kepada anggota keluarga yang lain, mengingat bahwa edukasi dari keluarga juga berperan besar dalam penyampaian informasi tentang kebersihan tangan. ${ }^{20}$

Keterbatasan dalam penelitian ini adalah dalam proses pengambilan data. Pada saat pengambilan data, terdapat beberapa responden yang sempat mengisi kuesioner secara berdiskusi dengan anggota keluarga lainnya. Pada penelitian selanjutnya, diharapkan peneliti memberi jarak antar responden ketika proses pengisian kuesioner berlangsung.

\section{KESIMPULAN DAN SARAN}

Persepsi dan pengetahuan mayoritas responden, dalam hal ini pengunjung ICU RSA UGM Yogyakarta terhadap hand hygiene dalam kategori yang baik. Persepsi dan pengetahuan pengunjung pada tiap domain sebagian besar juga dalam kategori baik.

Saran bagi instansi kesehatan untuk mengevaluasi kebijakan terkait hand hygiene. Bagi peneliti selanjutnya, diharapkan dapat melakukan penelitian terkait hand hygiene pengunjung lebih banyak dan lebih mendalam.

\section{UCAPAN TERIMAKASIH}

Penelitian ini didanai oleh Program Studi Ilmu Keperawatan FK-KMK UGM. Terima kasih kepada asisten penelitian serta responden yang telah membantu proses penelitian sehingga penelitian berjalan lancar.

\section{DAFTAR PUSTAKA}

1. Vincent J-L, Singer M, Marini JJ, Moreno R, Levy M, Matthay MA, et al. Thirty Years of Critical Care Medicine. Crit Care. 2010; 14(3): 311.

2. Strich JR, Palmore TN. Preventing Transmission of Multidrug-Resistant Pathogens in The Intensive Care Unit. Infectious Disease Clinics of North America. 2017 Sep; 31(3): 535-50.

3. Salawati L. Pengendalian Infeksi Nosokomial di Ruang Intensive Care Unit Rumah Sakit. Jurnal Kedokteran Syiah Kuala. 2012; 12.

4. Hobbs MA, Robinson S, Neyens DM, Steed C. Visitor Characteristics and Alcohol-based Hand Sanitizer Dispenser Locations at The Hospital Entrance: Effect on Visitor Use Rates. American Journal of Infection Control. 2016 Mar; 44(3): 258-62.

5. Malacarne P, Corini M, Petri D. Health Care-Associated Infections and Visiting Policy in An Intensive Care Unit. American Journal of Infection Control. 2011 Dec; 39(10): 898-900. 
6. Munoz-Price LS, Banach DB, Bearman G, Gould JM, Leekha S, Morgan DJ, et al. Isolation Precautions for Visitors. Infect Control Hosp Epidemiol. 2015 Jul; 36(7): 747-58.

7. Birnbach DJ, Nevo I, Barnes S, Fitzpatrick M, Rosen LF, Everett-Thomas R, et al. Do Hospital Visitors Wash Their Hands? Assessing The Use of Alcohol-based Hand Sanitizer in A Hospital Lobby. American Journal of Infection Control. 2012 May; 40(4): 340-3.

8. Fauzia SS, Handiyani H. Tingkat Pengetahuan dan Perilaku Kebersihan Tangan pada Pengunjung Rumah Sakit. 2014; 9.

9. Ekarini P. Analisis Faktor yang Berhubungan dengan Perilaku Cuci Tangan Pengunjung Pasien Ruang Anak RSUD Dr. Sayidiman Magetan. Program Studi Magister Keperawatan Fakultas Kedokteran Universitas Gadjah Mada Yogyakarta. 2017.

10. World Health Organization, Editor. WHO Guidelines on Hand Hygiene in Health Care: First Global Patient Safety Challenge: Clean Care is Safer Care. Geneva, Switzerland: World Health Organization, Patient Safety; 2009. 262 p.

11. Putri AF. Pentingnya Orang Dewasa Awal Menyelesaikan Tugas Perkembangannya. SCHOULID Journal [Internet]. 2018 Jun 21 [cited 2020 Jun 20];3(2). Available from: https://jurnal.iicet.org/index.php/schoulid/article/view/430

12. Simamora $\mathrm{RH}$. Pengaruh Penyuluhan Identifikasi dengan Menggunakan Media Audiovisual terhadap Pengetahuan Pasien Rawat Inap. JKS. 2019 Nov 8; 3(1): 342-51.

13. Muhardi. Kontribusi Pendidikan dalam Meningkatkan Kualitas Bangsa Indonesia. 2004; (4): 15.

14. Styani E. Persepsi Keluarga tentang Waktu Berkunjung di Intensive Care Unit (ICU). 2017.

15. Topçu S, Alpar ŞE. Patient Experiences in Intensive Care Units: A Systematic Review. Patient Experience Journal. 2017; 4(3): 14.

16. El Marjiya Villarreal S, Khan S, Oduwole M, Sutanto E, Vleck K, Katz M, et al. Can Educational Speech Intervention Improve Visitors' Hand Hygiene Compliance? Journal of Hospital Infection. 2020 Apr; 104(4): 4148.

17. Ta'adi, Setiyorini E, Amalya MR. Faktor yang Berhubungan dengan Kepatuhan Cuci Tangan 6 Langkah Momen Pertama pada Keluarga Pasien di Ruang Anak. 2019: 8.

18. Notoatmodjo S. Ilmu Perilaku Kesehatan. Jakarta: Rineka Cipta; 2010.

19. Hendayana R. Modul Persepsi dan Adopsi Teknologi. Bogor: Balai Besar Pengkajian dan Pengembangan Teknologi Pertanian; 2014.

20. Foà C, Tura GA, Camelli C, Silingardi R, Kuenzer E, Carraro G, et al. Hand Hygiene in Healthcare Settings: The Citizens' Point of View. Acta Biomed for Health Professions. 2017; 88: 40-53.

21. Robbins SP, Judge TA. Essentials of Organizational Behavior. 14th Edition. Pearson; 2018. 95-100 p.

22. Ciofi degli Atti ML, Tozzi AE, Ciliento G, Pomponi M, Rinaldi S, Raponi M. Healthcare Workers' and Parents' Perceptions of Measures for Improving Adherence to Hand-Hygiene. BMC Public Health. 2011 Dec; 11(1): 466.

23. Pender N. The Health Promotion Model. University of Michigan. 2011; 19.

24. Taplitz RA, Ritter ML, Torriani FJ. Infection Prevention and Control, and Antimicrobial Stewardship. In: Infectious Diseases [Internet]. Elsevier; 2017 [cited 2019 Jun 13]. p. 54-61.e1. Available from: https://linkinghub.elsevier.com/retrieve/pii/B978070206285800006X

25. Aarestrup SC, Moesgaard F. Nudging Hospital Visitors' Hand Hygiene Compliance. 2017 [cited 2020 Jun 20]; Available from: http://rgdoi.net/10.13140/RG.2.2.25911.52641

26. Hess C, Ostrom E. Understanding Knowledge as A Commons: From Theory to Practice. London: The MIT Press; 2007.

27. Ratnawati L, Sianturi SR. Faktor - Faktor yang Berhubungan dengan Kepatuhan Perawat dalam Menerapkan Hand Hygiene. Jurnal IImu Keperawatan dan Kebidanan. 2018 Jul 23; 9(2): 148.

28. Cohen B, Hyman S, Rosenberg L, Larson E. Frequency of Patient Contact with Healthcare Personnel and Visitors: Implications for Infection Prevention. The Joint Commission Journal on Quality and Patient Safety. 2012 Dec; 38(12): 560-5.

29. Fajriyah NN. Pengetahuan Mencuci Tangan Penunggu Pasien Menggunakan Lotion Antiseptic. The $2^{\text {nd }}$ University Research Coloquium. 2015; 6.

30. Hagel S, Ludewig K, Pletz MW, Frosinski J, Moeser A, Wolkewitz M, et al. Effectiveness of A Hospital-Wide Infection Control Programme on The Incidence of Healthcare-Associated Infections and Associated Severe Sepsis and Septic Shock: A Prospective Interventional Study. Clinical Microbiology and Infection. 2019 Apr; 25(4): 462-8.

31. Satiti A, Frisca S, Nurjanah V. Hubungan Edukasi Cuci Tangan terhadap Pengetahuan, Sikap, dan Kemampuan Keluarga di Rumah Sakit X Palembang. 2019; 2: 10.

32. Van der Vegt DSJM, Voss A. Are Hospitals Too Clean to Trigger Good Hand Hygiene? Journal of Hospital Infection. 2009 Jul; 72(3): 218-20.

33. Banach DB, Bearman GM, Morgan DJ, Munoz-Price LS. Infection Control Precautions for Visitors to Healthcare Facilities. Expert Review of Anti-infective Therapy. 2015 Sep 2; 13(9): 1047-50. 